\title{
BIODIVERSITY STATUS OF URBAN REMNANT FORESTS IN CAPE COAST, GHANA
}

\author{
J. P. Deikumah, and A. A. Kudom, \\ Department of Entomology and Wildlife, School of Biological Sciences, University of Cape Coast, \\ Cape Coast. \\ stjustus25@yahoo.co.uk \\ adusandy@yahoo.co.uk
}

\begin{abstract}
Cape Coast Metropolis, which is close to Kakum forest, has its native forests being reduced to fragments. Biodiversity in these forest reserves are exposed to the threat of being cleared over night as a result of urbanization. There are reported cases of some rare or potential medicinal plant species that have disappeared from the Cape Coast environ and is worth noting that basic knowledge of the organisms that make up most of the ecosystems in these remnant forests are woefully inadequate. In this study, inventory of vertebrates and invertebrates were undertaken in five remnant forests in Cape Coast. The study sites were surveyed for small terrestrial mammals, large mammals, avifauna, herpetofauna and invertebrates. From the inventory taken, 15604 species of invertebrates belonging to 51 families, 83 species of birds belonging to 30 families were sampled. Furthermore 14 species of mammals belonging to 8 families and 8 species of herpetofauna were also sampled. Although these species were of least concern under IUCN category, it is important to protect these native forests from total destruction. Benefits such as the protection of numerous native pollinators and biological control agents can be derived when these reserves are protected. Furthermore, such reserves can be developed to become biological field stations for research or ecotourism parks which can generate employment and revenue for the community. Conservation of biodiversity is in the interest of generations unborn; not only Ghanaians or Africans but the whole of tomorrow's mankind.
\end{abstract}

Keywords: forest fragmentation; biodiversity; remnant forest; conservation; Cape Coast.

\section{INTRODUCTION}

The major threats to biological diversity that result from human activity include habitat destruction and habitat fragmentation. In addition to outright destruction, habitats that formerly occupied wide unbroken areas are now often divided into pieces by roads, fields, towns, and a broad range of other human constructs. In the past two decades there has been an in- creasing response to these ongoing threats with research being conducted in many different ecosystems using many methodologies (McGarigal and Cushman, 2002). Majority of these studies have been conducted in temperate ecosystems of the developed world and there is compelling evidence that changes to landscape composition and structure that accompany fragmentation are affecting species in many tem- 
perate countries (Robinson et al., 1995; Watson et al., 2003). However, there have been relatively few studies on the impact of habitat fragmentation and deforestation in tropical developing countries especially in Africa where the impact of deforestation seem to be most serious (Whitmore, 1997).

Cape Coast Metropolis, which is close to $\mathrm{Ka}$ kum forest, has its native forest being reduced to fragments as a result of habitat disturbances by human activities such as rapid pace of deforestation, pollution, logging and poaching. The most alarming aspect of this tropical forest crisis in Cape Coast Metropolis is the unparalleled threat to biological diversity. Conversion of contiguous forest into patches can dramatically alter biodiversity with some individual populations declining or disappearing and others becoming hyper-abundant (Bierregaard and Stouffer, 1998). Biodiversity in the forest reserves of Cape Coast Metropolis are exposed to the threat of being cleared over night as a result of urbanization and expansion. There are reported cases of some rare or potential medicinal plant species that have disappeared from the Cape Coast environment. For example, Ancistrocladus abbreviatus under the group of Ancistrocladaceae is among the disappeared plant species. A "sister plant" A. korupensis, which had been collected from Cameroon, had yielded michellamines a group of dimeric naphthylisoquinolines, possessing high anti-HIV activity (Tayman, 1999). There is the possibility that there are some other unknown species in these forest reserves, which could contain new potent alkaloids with activity against HIV and malaria.

It is worth mentioning that basic knowledge of the organisms that make up most of the ecosystems in these remnant forests are woefully inadequate. There is the need to establish an inventory and monitoring of the components of biodiversity in this remnant forests. It is as a result that this research was undertaken to assess biodiversity status of fauna in these remnant forests to whip up further studies towards conservation and management.

\section{MATERIALS AND METHODS}

Study area

Cape Coast Metropolis occupies an area of $122 \mathrm{sq} . \mathrm{km}$. The area is dominated by batholiths and generally undulating with steep slopes. There are valleys of various streams between the hills with Kakum being the largest stream. The minor streams end in wetlands, the largest of which drains into the Fosu Lagoon at Bakano. The area has double maxima rainfall totaling between $750 \mathrm{~mm}$ and $1000 \mathrm{~mm}$, with the major rainy season between May and July and the minor rainy season between November and January. Cape Coast is a humid area with mean monthly relative humidity varying between $85 \%$ and $99 \%$. The sea breeze has a moderating effect on the local climate. The present vegetation of the metropolis consists of shrubs of about $1.5 \mathrm{~m}$ high, grasses and remnant forest fragment thickets. The study was carried out in the remnant forest reserves or the forest fragments which are best described as coastal thickets located at Adisadel College, Saint Augustine's College, University of Cape Coast and Holy Child School (pristine coastal thicket) and Mfantsipim School (secondary forest).

\section{Survey methodology}

The five study sites were surveyed for large and small terrestrial mammals, avifauna, herpetofauna (amphibian and reptiles) and invertebrates. Methods for survey and handling of mammals were mainly as in Wilson et al. (1997), and Sutherland (2006). Happold and Happold (1990) was used for small mammal identification. Main reference for herpetofauna was Hughes (1988). Bird identification and survey techniques followed Borrow and Demey (2001) and Bibby et al. (1998) respectively. Arthropods and other invertebrates were identified to the family level at the entomological museum of university of Cape Coast.

\section{Mammals}

Information on large mammals was obtained by direct observation and examination of spoor along trails and transect in various parts of the study area. The information was gathered dur- 
ing the day and at dusk and dawn. Additional information was obtained by interviewing hunters, "bushmeat" sellers and "chopbar" operators within the fringe communities. Pictures in field guides (Happold and Happold, 1990; Booth, 1966; Meester and Setzer, 1971) were shown to the local people to help in the identification of the mammals.

For small terrestrial mammals, each of the five study sites 20 Sherman's (entrance size $9 \mathrm{~cm} \mathrm{x}$ $7 \mathrm{~cm}$ ) and Longworth's (entrance size $6 \mathrm{~cm} \mathrm{x}$ $5.3 \mathrm{~cm}$ ) live traps were alternately placed along 400 meter transects through representative habitat types at 10 meter intervals. All traps were pre-baited for one night followed by two nights trapping with bait made from maize (corn) powder and groundnut (peanut) paste. Traps were set in the evening (16:30 to $18: 00$ hrs. UT) and inspected early in the morning (06:30 to 07:30 hrs. UT). All captured animals were put in a large transparent polythene bag, identified, sexed and released.

\section{Avifauna}

Birds' survey was conducted using point counts and mist-netting. Direct observations including visual as well as vocal records were made to determine bird species occurrence. With the mist-netting, two standard $12 \mathrm{~m}$ mist nets (height 2.6 with 4 shelves) were erected in each of the five study sites for 3 days (0600 to 1800 hrs. UT). The nets were inspected every 30 minutes and all birds caught identified, recorded and released. Some information was also obtained from the local people through interviews.

\section{Herpetofauna}

Reptiles and amphibians survey involved casual observations and refuge examination (i.e. searching under rocks, logs, in rotten tree stumps, in leaf litter, old termite mounds and rodent burrows). In addition pit falls in association with drift fences were used to trap amphibian and reptiles especially around ponds and streams. Some information was also obtained from the local people through interviews.

\section{Invertebrates}

Plots of $20 \mathrm{~m}$ x $20 \mathrm{~m}$ were selected randomly and invertebrates found within these plots were collected and identified. Collections were done to cover different areas of the forest including the forest floor, decomposing wood, soil, tree trunks and open air, using aspirators, pitfall trap, malaise trap, sweep net, aerial net and direct hand picking using forceps. The specimens collected were sent to laboratory and the museum for identification and storage.

\section{RESULTS}

\section{Mammals and Herpetofauna}

Mammals recorded within the period of survey in the study area are presented in Table 1. A total of fourteen species of mammals were recorded belonging to eight families with different occurrence in the study sites. Out of thirteen species of mammals reported by inhabitants in the local area, only five species were sighted during the ecological survey. Also spoors and signs of three species were encountered. Thryonomys swinderianus and Galago senegalensis were reported in all study sites but not sighted within the period of study. Herpetofauna comprising Bufo regularis, Phrynobatrachus alleni, Phrynobatrachus aecraensis, Ptychadena bibroni, and Ptychadena aeuguiplicata were sampled. It also included green mamba, monitor lizard, skink and Chameleon.

\section{Avifauna}

Different species of birds in the various study sites and their families are summarized in Table 2. A total of 83 different species belonging to 30 families were encountered in all the five study sites. The University of Cape Coast forest reserve recorded the highest number (69 species), 50 species were recorded in Adisadel college reserve, 38 in Mfantsipim school reserve, 34 in St. Augustine college reserve and Holy Child school reserve recorded 30 species which was the least. Adisadel College and University of Cape Coast remnant forest reserves had 44 species overlapping, 25 species present in the latter but absent in the former, 8 species absent in both sites and 7 species present in 
Adisadel College but absent in University of Cape Coast forest reserve. There were 27 species overlapping in both Holy Child and University of Cape Coast forest reserves, 12 absent in both sites, 4 present in the former but absent in the latter and 42 species occurred in University of Cape Coast but not in Holy Child school reserve. A total of 19 species overlapped in all the study sites. Birds in all study sites were less diverse (Table 4).

Table 1: Mammal species sampled in selected remnant forests in Cape Coast Metropolis.

\begin{tabular}{|c|c|c|}
\hline Family & Spices & $\begin{array}{l}\text { Common } \\
\text { Name }\end{array}$ \\
\hline $\begin{array}{l}\text { Cercopitheci- } \\
\text { dae }\end{array}$ & $\begin{array}{l}\text { Chlorocebus } \\
\text { sabaeus } \\
\text { Cercopithecus } \\
\text { petaurista }\end{array}$ & $\begin{array}{l}\text { Green Mon- } \\
\text { key } \\
\text { Lesser spot- } \\
\text { nosed monkey }\end{array}$ \\
\hline Galagidae & $\begin{array}{l}\text { Galago sene- } \\
\text { galensis }\end{array}$ & Bush baby \\
\hline Herpestidae & $\begin{array}{l}\text { Galerella san- } \\
\text { guine } \\
\text { Crossarchus } \\
\text { obscures }\end{array}$ & $\begin{array}{l}\text { Mongoose } \\
\text { Kusimanse }\end{array}$ \\
\hline $\begin{array}{l}\text { Thryonomyi- } \\
\text { dae }\end{array}$ & $\begin{array}{l}\text { Thryonomys } \\
\text { swinderianus }\end{array}$ & Grass cutter \\
\hline Procariidae & $\begin{array}{l}\text { Dendrohyrax } \\
\text { dorsalis }\end{array}$ & Tree hyrax \\
\hline Bovidae & $\begin{array}{l}\text { Neotragus } \\
\text { pygmaeus } \\
\text { Cephalophus } \\
\text { rufilatus } \\
\text { Philantanba } \\
\text { maxwellii } \\
\text { Tragelaphus } \\
\text { scriptus }\end{array}$ & $\begin{array}{l}\text { Royal ante- } \\
\text { lope } \\
\text { Red flanked } \\
\text { duiker } \\
\text { Maxwell's } \\
\text { duiker } \\
\text { Bushbuck }\end{array}$ \\
\hline Sciuridae & $\begin{array}{l}\text { Xerus erythro- } \\
\text { pus } \\
\text { Protoxerus } \\
\text { stranger }\end{array}$ & $\begin{array}{l}\text { West African } \\
\text { ground squir- } \\
\text { rel } \\
\text { Giant forest } \\
\text { squirrel }\end{array}$ \\
\hline Nesomyidae & $\begin{array}{l}\text { Cricetomys } \\
\text { gambianus }\end{array}$ & Giant rat \\
\hline
\end{tabular}

\section{Invertebrates}

From the inventory taken, 15604 species of invertebrates belonging to 51 family taxa were sampled. Among the arthropods, insects, comprising 13628 individual species belonging to 36 family taxa represented $87.34 \%$ of the entire invertebrate collection. Lepidopterans were the most abundant $(34.41 \%)$ among the insects followed by coleopteran (12.27\%), hymenopteran $(10.91 \%)$ and the rest being less than $10 \%$. Twelve termitaria with numerous termites were observed, however, termites were regarded as innumerable so they were not factored in the computation and also we were not able to classify termites to the family taxon. Arachnids were the second most abundant class of invertebrates, comprising 1449 individuals representing $9.29 \%$ of the entire invertebrate collection. Of the arachnids, 1340 individual species were spiders and 109 individual species were scorpions. Of about 25 families of spiders dwelling in the forest, 8 families were observed in this study. Only woodlice belonging to two families in Order Isopoda were sampled under crustaceans. Insects, arachnids and crustaceans have been summarized in Table 3. The rest of the invertebrates sampled including millipedes (Spirostrepida: Spirostreptidae), centipedes (Craterostigmorpha: Craterostigmidae), annelids (Haptotaxidea: Lumbricidae), and mollusk (Stylommatophora: Aroinidae) were few in number and none recorded $>0.55 \%$ of the entire collection. Invertebrates were highly diverse in all the study sites (Table 4).

\section{DISCUSSION}

Protecting habitats that contain healthy intact biological communities is the most effective way to conserve biological diversity. Though the results from this study shows that almost all the fauna in the remnant forest in Cape Coast metropolis were of least concern under IUCN 2008 , it is important to protect these native forest from total destruction. The role of different species in medicine is of particular interest to conservation biologists because it so clearly highlights the need to maintain biodiversity. 
Table 2: Bird species sampled in selected remnant forests in Cape Coast Municipality.

\begin{tabular}{|c|c|}
\hline Family & Species \\
\hline Accipitridae & $\begin{array}{l}\text { Milvus migrans, Accipiter bandius, Necrosyrtes monachus, Buteo augu- } \\
\text { ralis }\end{array}$ \\
\hline Alcedinidae & Ispidina lecontei, Halcyon senegalensis, Halcyon malimbica \\
\hline Apodidae & Apus affinis, Apus apus, Cypsiurus parvus \\
\hline Ardeidae & Bubulcus ibis, Egreta intermedia \\
\hline Bucerotidae & Tockus fasciatus, Tockus nasutus \\
\hline Capitonidae & Lybius bidenatus, Progoniulus chrysoconus, Progoniulus subsulphureus \\
\hline Columbidae & $\begin{array}{l}\text { Streptopelia semitorquata, Turtur abyssinicus, Turtur afer, Streptopelia } \\
\text { senegalensis, Columba unicincta, Columba iriditorques, Streptolia vina- } \\
\text { cea }\end{array}$ \\
\hline Corvidae & Corvus albus \\
\hline Cuculidae & $\begin{array}{l}\text { Centropus senegalensis, Chrysococcyx caprius, Chrysococcyx } \\
\text { cupreus, Cuculus canorus, Cuculus solitaries }\end{array}$ \\
\hline Dicruridae & Dicrurus ludwigii \\
\hline Estrildidae & Lagonosticta rufopicta, Sphermophaga haematina, Estrilda melpoda \\
\hline Falconidae & Falco biarmicus, Falco ardosiaceus, Falco rupicolor \\
\hline Hirundinidae & Hirundo rustica \\
\hline Indicatoridae & Indicator maculatus \\
\hline Laniidae & Lanius collaris \\
\hline Malaconotidae & $\begin{array}{l}\text { Spermestes bicolor, Dryoscopus gambensis, Tchagra senegala, } \\
\text { Laniarus barbarous }\end{array}$ \\
\hline Meropidae & Merops albicollis, Merops pusillus \\
\hline Motacillidae & Anthus leucophrys \\
\hline Muscicapidae & Ficedula hypoleuca \\
\hline Musophagidae & Tauraco macrohynchus, Crinifer piscator \\
\hline Nectariiniae & $\begin{array}{l}\text { Cinnyris coccinigastrus, Cinnyris cupreus, Cinnyris chloropygius, } \\
\text { Hedydipna collaris, Cinnyris superbus, Cyanomitra olivacea }\end{array}$ \\
\hline Passeridae & Passer griseus \\
\hline Picidae & Sasia Africana, Dendropicos pyrrhogaster \\
\hline Platysteiridae & Dyaphorophyia castanea, Platysteira cyanea \\
\hline Ploceidae & $\begin{array}{l}\text { Ploceus cucullatus, Ploceus luteolus, Ploceus nigricollis, Ploceus ocularis, } \\
\text { Malimbus nitens, Malimbus scutatus }\end{array}$ \\
\hline $\begin{array}{l}\text { Pycnonotidae } \\
\text { Sturnidae }\end{array}$ & $\begin{array}{l}\text { Pycnonotus barbatus, Chlorocichla simplex, Andropadus virens Lampro- } \\
\text { tornis splendidus }\end{array}$ \\
\hline Sylviidae & $\begin{array}{l}\text { Camaroptera brevicaudata, Cisticola erythrops, Cisticola cantans, } \\
\text { Prinia subflava, Phylloscopus trochilus, Phylloscopus sibilatrix, Hippo- } \\
\text { lais pallid, Hyliota violacea, Macrosphenus concolor, Cisticola natalen- } \\
\text { sis, Hippolais polyglotta }\end{array}$ \\
\hline Threskiornithidae & Plegadis falcinellus \\
\hline Zosteropidae & Zosterops senegalensis \\
\hline
\end{tabular}


Table 3. Arthropod species sampled in selected remnant forests in Cape Coast Municipality.

\begin{tabular}{|c|c|c|}
\hline Class & Order & Family \\
\hline \multirow[t]{9}{*}{ Insecta } & Lepidoptera & $\begin{array}{l}\text { Nymphalidae, Papillionidae, Pieridae, Hesperiidae, } \\
\text { Noctuidae, }\end{array}$ \\
\hline & Coleoptera & $\begin{array}{l}\text { Cerambycidae, Scarabaeidae, Carabidae, } \\
\text { Coccinellidae }\end{array}$ \\
\hline & Neuroptera & Chrysopidae, Berothidae \\
\hline & Diptera & $\begin{array}{l}\text { Calliphoridae, Tabanidae, Syrphidae, Muscuidae, Chironomi- } \\
\text { dae, Tipulidae, Culicidae }\end{array}$ \\
\hline & Hymenoptera & $\begin{array}{l}\text { Apidae, Megachilidae, Halictidae, Formicidae, Sphecidae } \\
\text { Vespida, Agaonidae }\end{array}$ \\
\hline & Odonata & Aeshnidae, Gomphidae, Macromiidae \\
\hline & Orthoptera & Acrididae, Tettigoniidae, Gryllidae \\
\hline & Hemiptera & $\begin{array}{l}\text { Pyrrhocoridae, Acanthosomatidae, Pentatomidae, Miridae, } \\
\text { Rhopalidae }\end{array}$ \\
\hline & Dictyoptera & Blattidae \\
\hline \multirow[t]{2}{*}{ Arachnida } & Araneae & $\begin{array}{l}\text { Lycosidae, Salticidae, Araneidae, Linyphiidae, } \\
\text { Pholicidae,Agelenidae, Gnaphosidae, Theraphosidae }\end{array}$ \\
\hline & Scorpiones & Scorpionidae \\
\hline Crustacea & Isopoda & Orniscidae, Armadillidiidae \\
\hline
\end{tabular}

Table 4. Simpson index (D) of invertebrates, birds and mammals in the remnant forests in Cape Coast Metropolis.

\begin{tabular}{llcl}
\hline Remnant Forest Reserves & \multicolumn{3}{c}{ Simpson Index } \\
& Invertebrates (N) & Birds (N) & Mammal (N) \\
\hline Adisadel College forest reserve & $0.047(2331)$ & $0.953(362)$ & $0.997(46)$ \\
Mfantsipim School forest reserve & $0.042(2431)$ & $0.918(230)$ & $0.994(35)$ \\
St. Augustine College forest reserve & $0.036(2306)$ & $0.916(255)$ & $0.993(13)$ \\
Holy Child School reserve & $0.035(1887)$ & $0.951(361)$ & $0.996(43)$ \\
University of Cape Coast forest reserve & $0.042(2962)$ & $0.918(573)$ & $0.993(44)$ \\
& & & \\
\hline
\end{tabular}


From a biochemical perspective every species is unique and thus potentially could be the source of a major scientific break-through. If we lose a species we may have lost an invaluable opportunity. Also, Information on the rate of depletion and extent of extinction of species has not been compiled yet in Ghana. So we don't know local endangered species or species that need special attention. It is against this background that we have to consider the prospects of conserving or protecting these remnant forests from total destruction. Massive disturbances caused by people have altered, degraded, and destroyed the natural landscape of these remnant forests. Many species in these forests have lost the greater areas of their habitat to agricultural activities, urbanization and expansion. In addition, environmental pollution especially disposal of solid waste into the forest is eliminating many species from biological community, even where the structure of the community is not obviously disturbed. These activities have also decreased species' richness and evenness of mammals and birds in these remnant forests.

However, there are a lot of benefits that can be derived from these forests when protected. They house numerous invertebrates especially insects that may be pollinators or biological control agents. Agrosystems and wild lands may be losing the pollinator communities that are critical to their productivity. There are welldocumented losses of pollinators (Buchmann and Nabhan, 1996). Central and South America native bee populations are declining in several disturbed habitats, including fragmented natural ecosystems (Lima-Verde and Freitas, 2002) and this has reduced effective pollination of cocoa in these countries (Winder and Silva, 1972). Some countries have initiated programmes encouraging the conversion of croplands by farmers to forests and grasslands with the aim of restoring pollinator populations and improving natural ecosystems. Fortunately, we already have the forest, though disturbed; it can be protected from further destruction or restored. Sustaining pollinator species and numbers should be sufficient incentive for conserving these remnant forests. Furthermore, they can also be developed into biological field stations, which can combine biodiversity protection and research with conservation education. This facility can be used by universities or other research organizations.

Some of the remnant forests had monkeys especially lesser spot-nosed monkey, which is a charismatic animal that can attract tourist if their habitat is protected and developed into an ecotourist park. The forest also housed many birds that are crucial to ecotourism, especially if they are developed into bird watching sites. In the process of protecting these charismatic animals, whole communities that may consist of thousands of other species and their associated ecosystem processes are also protected. In addition, these parks can generate employment or revenue for the community.

This study has provided baseline information on the status of fauna in these remnant forests in Cape Coast, however there is a need for further studies especially on population and bioecology of the animals.

\section{CONCLUSION}

Remnant forests in Cape Coast metropolis housed a lot of fauna, though most of the species were of least concern under IUCN category, it is worth protecting these native forests and their biodiversity from total destruction. This survey has provided baseline information about the fauna in these remnant forests and this will help to develop conservation strategies to protect the biodiversity in these forests. The species list generated from this study will also help to monitor individual species in the forest. If remnant forests can house such a numerous biodiversity, then it is very important to protect them especially from over hunting and physical habitat destruction such as disposal of solid waste in and around the forests. Conservation of biodiversity is in the interest of generations unborn; not only Ghanaians or Africans but the whole of tomorrow's mankind. 


\section{REFERENCES}

Bibby, C., Jones, M. and Marsden, S. (1998). Expedition field techniques; Bird surveys, Expedition Advisory Centre, London.

Bierregaard, R. O. and Stouffer, P. C. (1998). Understory birds and habitat mosaics in Amazonian rainforests. In: Laurence, W.F. and Bierregaard Jr., R.O. (Editors) Tropical forest remnants: ecology, man agement and conservation of fragmented communities. University of Chicago press, Chicago.

Borrow, N. and Demey, R. (2001). Helm Identification Guides: Birds of Western Africa, Christopher Helm Publishers.

Booth, A. H. (1966). Small mammals of West Africa. Longmans, Green and Co Ltd, UK.

Buchmann, S. L. and Nabhan, G. P. (1996). The forgotten pollinators. Island Press, Washington, D.C.

Happold, C. D. C. and Happold, M. (1990). The mammals of Nigeria. Oxford University Press.

Hughes, B. (1988). Herpetology on Ghana (West Africa). British herpetology Society 25:29-38.

Lima-Verde, L. W and Freitas, B. M. (2002). Occurrence and biogeographic aspects of Melipona quinquefasciatain NE Brazil (Hymenoptera, Apidae). Brazilian Journal of Biology 62(3): 479-486.

McGarigal, K. and Cushman, S. A. (2002). Comparative evaluation of experimental approaches to the study of habitat fragmentation effects. Ecological Application 12:335-345
Meester, A. J. and Setzer, H. W. (1971). The Mammals of Africa, and identification manual. The Smithsonian Institute, Wash ington, D.C.

Robinson, S. K., Thompson, F. R., Donovan, T.M., Whitehead, D.R., and Faaborg J. (1995). Regional forest fragmentation and the nesting success of migratory birds. Science, 267:1987-1990

Sutherland, W. J. (2002). Ecological census techniques. $2^{\text {nd }}$ ed. Cambridge University Press, UK.

Tayman, K. F. S (1999). The need to conserve biodiversity. Journal of Natural Sciences 1:11-23

Watson, J. E. M., Paul, A. W. I., and Freudenberger, D. (2003). Woodland fragmentation is causing the decline of species and functional groups of birds in south eastern Australia. Pacific conservation biology, 8:261-270

Whitmore, T. C. (1997) Tropical forest disturbance, disappearance and species loss. In: Laurence, W.F. and Bierregaard Jr., R.O. (Editors) Tropical forest remnants: ecology, management and conservation of fragmented communities. University of Chicago press, Chigago.

Wilson, D. E., Cole, F.R., Nicholas, J. D., Rudran, R. and Foster, M.S. (1997). Measuring and Monitoring Biological Diversity: standard Methods for Mammals. Smithsonian Institute Press, Wash ington, D.C

Winder, J. A. and Silva, P 1972. Cacao pollination: Microdiptera of cacao plantations and some of their breeding places. Bulletin of Entomology Research 61:651 - 655. 